\title{
Do Crises Change the Percieved Performance of Female Leaders versus Male Leaders from the Standpoint of Junior Level Employees?
}

\author{
Emine Banu Çelebi ${ }^{1} \&$ Ezgi Yildirim Saatci ${ }^{2}$ \\ ${ }^{1}$ Social Entrepreneurship Research Center, Okan University, Formula 1 Yolu Tuzla Campus, Akfirat İstanbul, \\ Turkey \\ ${ }^{2}$ Social Entrepreneurship Research Center, Department of Management, Okan University, Formula 1 Yolu Tuzla \\ Campus, Akfirat İstanbul, Turkey \\ Correspondence: Asst. Prof Ezgi Yildirim Saatci, Social Entrepreneurship Research Center, Department of \\ Management, Okan University, Formula 1 Yolu Tuzla Campus, Akfirat İstanbul 34959 Turkey.
}

Received: January 5, 2016

doi:10.5430/jms.v7n1p45
Accepted: January 25, 2016

Online Published: February 11, 2016

URL: http://dx.doi.org/10.5430/jms.v7n1p45

\begin{abstract}
The difference between men and women was and will probably always remain to be an interesting research field for academics and practioners of all disciplines. From the management perspective, ass more and more women enter the workforce, the traditional workforce demographics are changing with an increasing tendency of women in leadership roles. Yet, the question of whether there are fundamental differences between the leadership behaviors of men and women remain crucial.

This paper investigates the role of women managers versus male associates' leading performances during the economic crises faced by the organizations through the lenses of junior level employees' perception within an integrative approach of organizational theories of leadership, gender studies and crisis management. In accordance, the research question of "Do the junior level employees perceive women to be the "better leaders" in times of crisis and men to be the "better leaders" in times of tranquility? is addressed and two hypothesis are tested to find out this relationship on the axis of favorably evaluation and recommendation for leadership positions.
\end{abstract}

Keywords: leadership, gender, employee perception, social identity, crises management

\section{Introduction}

By the end of the $19^{\text {th }}$ century, research on leadership theories revived and a variety of approaches such as the trait, behavioral and the contingency started to form. From these approaches, the transformational and the charismatic leadership were developed. These theories shared the idea that an appealing and commonly shared vision is a leader's most important attribute (Strange and Mumford, 2002) and that this vision becomes even more important in a crisis situation (Berson et al., 2001). Furthermore, there is general agreement among theorists that charismatic leaders are more likely to emerge when a company's performance is in a state of crisis (e.g., Conger \& Kanungo, 1987; Yukl, 1998).

Dimension of gender differences is also included within the domain of leadership in an effort to differentiate leader form others. Although some theorists found no significant differences in the leadership styles of men and women (e.g., van Engen et al., 2001,) and disregarded the gender stereotypes other theorists like Loden (1985) argued that men have a more masculine, agentic leadership style (with traits such as competitiveness, hierarchy and power), in contrast to women who prefer a more feminine, communal leadership style (with traits such as cooperation, equality and support).

The field of gender and leadership has tried to assess the underrepresentation of women in management positions and the possible explanatory factors for this gender inequality such as (Ryan \& Haslam, 2007). Some of these explanatory factors include; the obvious sexism in the work place (e.g., Schwartz, 1994), the perceived unsuitability between women's capability as a leader and the necessities of true leadership (e.g., Arvey, 1979; Schein, 1973), women's responsibilities at home and work - family conflicts (e.g., Schwartz, 1994) and women's fear of success (e.g., Horner, 1972). 
On the other hand, since the end of the $20^{\text {th }}$ century, the research on the gender differences literature mainly concentrated around the question of why women are not able to make it to the top with "glass ceiling" phenomenon. (e.g., Ridgeway, 2001; Arfken et al., 2004; Maume, 2004) By 2000s "glass cliff phenomenon" emerged explaining that more and more women are breaking through the glass ceiling, but are only offered positions that are riskier than the positions offered to men. While men turn these positions down (in order not to fall short in case of failure) women accept it, and when failure does occur, they have to face the consequences and get blamed much more often than men (Ryan and Haslam, 2004).

Nevertheless, recent researches suggest that women are starting to progress in career paths (e.g., Dreher, 2003; Goodman et al., 2003; Ryan \& Haslam, 2007). Yet, the participation rates are still below for most of the countries. For instance, according to Turkish Statistical Institute (2013) women represented just over \%30 of the 24 million total labor forces in Turkey as reported by World Bank Report and stated in Figure 1.

\begin{tabular}{|c|c|c|c|c|c|c|c|c|c|}
\hline & \multicolumn{3}{|c|}{ TURKEY } & \multicolumn{3}{|c|}{ URBAN } & \multicolumn{3}{|c|}{ RURAL } \\
\hline YEARS & \begin{tabular}{|l} 
NUMBER OF \\
UNEMPLOYED \\
\end{tabular} & $\begin{array}{l}\text { UNEMPLOYMENT RATE } \\
(\%)\end{array}$ & \begin{tabular}{|l|} 
NON AGRICULTURAL \\
UNEMPLOYMENT \\
RATE $(\%)$
\end{tabular} & $\begin{array}{l}\text { NUMBER OF } \\
\text { UNEMPLOYED } \\
\end{array}$ & $\begin{array}{l}\text { UNEMPLOYMENT } \\
\text { RATE }(\%)\end{array}$ & \begin{tabular}{|l|} 
NON \\
AGRICULTURAL \\
UNEMPLOYMENT \\
RATE $(\%)$ \\
\end{tabular} & $\begin{array}{l}\text { NUMBER OF } \\
\text { UNEMPLOYED }\end{array}$ & $\begin{array}{l}\text { UNEMPLOYMENT } \\
\text { RATE (\%) }\end{array}$ & $\begin{array}{l}\text { NON AGRICULTURAL } \\
\text { UNEMPLOYMENT RATE } \\
\text { (\%) }\end{array}$ \\
\hline \multicolumn{10}{|l|}{\begin{tabular}{|l|} 
FEMALE \\
\end{tabular}} \\
\hline 2004 & 622 & 11,0 & 19,6 & 544 & 17,9 & 19,6 & 78 & 3,0 & 19,9 \\
\hline 2005 & 642 & 11,2 & 18,7 & 551 & 17,0 & 18,5 & 92 & 3,6 & 19,9 \\
\hline 2006 & 658 & 11,1 & 17,9 & 560 & 16,4 & 17,7 & 97 & 3,9 & 19,5 \\
\hline 2007 & 660 & 11,0 & 17,3 & 566 & 16,1 & 17,1 & 95 & 3,8 & 19,0 \\
\hline 2008 & 734 & 11,6 & 18,1 & 622 & 16,6 & 17,8 & 112 & 4,3 & 20,9 \\
\hline 2009 & 979 & 14,3 & 21,9 & 832 & 20,4 & 21,5 & 147 & 5,3 & 24,6 \\
\hline 2010 & 959 & 13,0 & 20,2 & 821 & 18,7 & 19,9 & 138 & 4,6 & 22,2 \\
\hline 2011 & 885 & 11,3 & 17,7 & 770 & 16,5 & 17,7 & 115 & 3,6 & 17,6 \\
\hline 2012 & 883 & 10,8 & 16,4 & 771 & 15,5 & 16,5 & 112 & 3,5 & 15,6 \\
\hline 2013 & 1033 & 11,9 & 17,4 & 885 & 16,4 & 17,3 & 148 & 4,5 & 18,1 \\
\hline $2014^{*}$ & 1040 & 11,9 & 16,5 & & & & & & \\
\hline
\end{tabular}

Source: Labour Force Statistics, 2004-2014 http://www.tuik.gov.tr/alt_id=1007

Figure 1. Female laborforce participation in Turkey 2004-2014

When it comes to glass ceiling, still women representation is not significant with rates such as $8.5 \%$ of Board membership, $8.2 \%$ of director in supervision committees and only $7 \%$ of director in corporate management committees are

female (http://siteresources.worldbank.org/TURKEYEXTN/Resources/361711_1268839345767/Female_LFP-en.pdf) as shown in Figure 2.

\begin{tabular}{l|l|l|l}
\multicolumn{1}{c|}{$\mathbf{2 0} \mathbf{2 0} \%$} & \multicolumn{2}{c|}{$\mathbf{5 - 1 0 \%}$} & \multicolumn{1}{c}{$<5 \%$} \\
\hline Finland & Australia & Belgium & Bahrain \\
\hline Norway & Austria & Brazil & Chile \\
\hline Sweden & Canada & China & India \\
\hline United Kingdom & Denmark & Greece & Japan \\
\hline & France & HK China & Kuwait \\
\hline & Germany & Indonesia & Oman \\
\hline & Israel & Ireland & Portugal \\
\hline & Netherlands & Italy & Qatar \\
\hline & Poland & Malaysia & Rep. of Korea \\
\hline & South Africa & Mexico & Russia \\
\hline & Turkey & New Zealand & Saudi Arabia \\
\hline & Switzerland & Singapore & Taiwan \\
\hline & USA & Spain & UAE \\
\hline & & Thailand & \\
\hline & & & \\
\hline
\end{tabular}

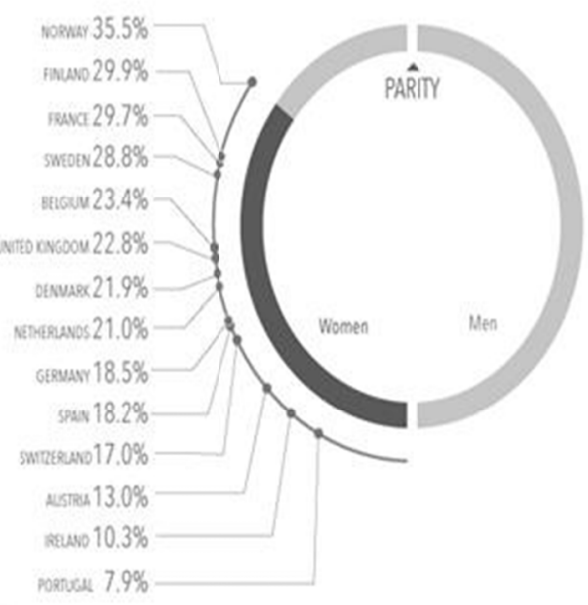

Source:

Catalyst

Knowledge

Center,

http://www.catalyst.org/knowledge/2014-catalyst-census-women-board-directors

Figure 2. Percentage of women participation in senior level management roles 
Due to the continued existence of differences, it is perceived and/or crucial to further investigate male / female contributions into organization studies, as a critical issue, and recognize it can add valuable and important contributions to the field, where traditional organization theories have still left much in vogue and especially during the time of crises. (Calas and Smircich, 2006)

\section{Literature Review}

\subsection{Leadership Theories}

Leader based examples are prevalent throughout the history but only recently, from the beginning of the twentieth century, has leadership theories took its place in organizational behavior related researches on the grounds of power as "the capacity of individuals to overcome resistance on the part of others, to exert their will, and to produce results consistent with their interests and objectives" (Buchanan \& Huczynski, 2004, p828).

In order to define leadership related research studies, the first known approach was the trait approach that attempt to compare leaders from non-leaders with specific focus on superior qualities. Conveyed leadership characteristics included drive, motivation, honesty, integrity, self-confidence and cognitive ability (Kirkpatrick \& Locke, 1991).

The behavioral approach to leadership pioneered in the 1950s at the Ohio State University and the University of Michigan. This theory, in short, focused on the behavior kinds of people in leadership and identified that leadership behaviors could be grouped in two major types: consideration and initiating structure (Landy \& Conte, 2004). Mutual trust, respect, and a certain warmth and rapport between the supervisor and group are included by consideration (Landy \& Conte, 2004). In other words, how much the leader is concerned with his/her subordinates, and the manner in which he/she treats them. Starting structure included behavior in which the supervisor organizes and defines group activities and his relation to the group (Landy \& Conte, 2004). In other words, how a leader succeeds in communicating to his/her subordinates that their task must be completed.

The earlier researches in the area of leadership theories concentrated mainly on the traits or the behaviors of leaders, with paying little or no attention for the effect of situational or environmental variables. The contingency approach proposed to take into account the role of the situation in the field of leadership (Landy \& Conte, 2004). Historically, Fiedler (1967) developed one of the first possible theories called the Least-preferred Coworker (LPC) Contingency Model or the Contingency Model of leadership effectiveness. The LPC Contingency Model "describes how the situation moderates the relationship between leadership effectiveness and a trait measure called the LPC" (Yukl, 1998).

After 1980s, transformational and charismatic leadership theories gained significance as well. In 1978, Burns' book "Leadership" created the base for transformational leadership theory. According to Burns (1978), transformational leadership is the back-and-forth between leaders and followers where each nurtures the other to higher levels of standards through motivation. The leader transforms the followers by appealing to their upright motives such as peace, trust, justice, and equality. A charismatic leader is defined to be the one who possess exceptional qualities which are accepted by their followers in an unconditional way with the guidance of leader's mission, visions and tactics for achievement (Willner, 1984). Charisma "is most often associated with a personal attribute of a leader that almost hypnotizes followers and compels them to identify with and emulate the leader" (Landy \& Conte, 2004, p.32). "These leaders represent revolutionary social forces, and they are responsible for significant societal transformations" (House \& Baetz, 1979, p: 399).

\subsection{Gender and Leadership}

From the gender point of view, leadership literature, until the 1980s, has assumed that leaders were men with special qualities. Furthermore, most of the research in this field has been conducted by men, whose subjects were men (Buchanan \& Huczynski, 2004). It is argued that women are rendered 'structurally powerless' in being restricted to routine, low-profile jobs, as well as facing discrimination in promotion decisions. (Michelle et al 2010; Moran et al, 2011; Kelly et al. 2012; Lerbinger, 2012)

There is considerable disagreement among researchers concerning the extent to which men and women differ on characteristics associated with leadership. On one side, many studies have not find significant differences between the leadership styles of men and women claim to not remain fundamental (e.g., Nieva \& Gutek, 1981; Lefkoitz, 1994; Hyde \& Plant, 1995; van Engen et al., 2001, Michelle et al 2010; Lerbinger, 2012). On the other side, the differences of gender related characteristics between the leadership styles are real and substantial (e.g., Gilligan, 1977; Ruble, 1983; Loden, 1985; Eagly, 1995 Moran et al, 2011; Kelly et al. 2012). 
Due to the natural and societal references associated to women -such as home keeper, child care taker and so on- not up to1990s, women were deeply scrutinized in the leadership research. Mann (1995) similarly argues that "women are underrepresented in leadership and management roles because they are less successful in acquiring power.

Today, companies are affected by politics and external factors deeply; therefore many various sizes of crises happen during the life time of a company. Crises can cause many situations where some of them are fatal for the company but some of them show new opportunities. Seeing the benefit from the crises and acting in order to get minimum damage is the leader's main challenge today. Despite of the leadership qualities, crises management ability is also required for today's leaders. Crises management is different than the tranquility-time management, as in crises, leaders should emphasize intuitive way of managing with the help of analytical thinking. Multi-tasking, fast thinking and fast deciding abilities are more important in crises times where taking responsibilities of the decisions and acting according to the consequences of these actions are critical.

In 1990, Eagly \& Johnson conducted a meta-analysis on the laboratory studies done in the period from 1961-1987 and found that women were more likely to use a more democratic and interpersonally oriented style, compared with men who were more likely to use a relatively autocratic and task-oriented leadership style. However, no such differences were found when they examined field studies. This suggested that stereotypes might have been operating in lab studies but not in real organizations. In field studies, however, Eagly \& Johnson (1990) determined that democratic and participative styles are preferred by women rather than the autocratic styles favored by men.

Eagly's (1995) gender role theory for instance, suggests that men and women are believed to have the traits that are necessary for the roles they generally occupy. These gender roles according to Eagly can be separated as the masculine attributes, which are named agentic, and the feminine attributes, which are called communal. Continuing, seeing as people strive to live up to their expectations, these stereotypes are likely to prove themselves to be right (Eagly et al., 2003). For this reason, women are challenged with difficulties to be able to become leaders, as they are not stereotypically perceived as leaders. For instance, women are more likely to use a transformational leadership style, which is seen as one of the most effective leadership styles in times of crisis ((Eagly et al., 2003).

The newer methods for studying leadership, such as transformational, charismatic and visionary styles, brought forth another direction to the research on gender differences in leadership styles. The transformational leadership style is often seen as the feminine leadership style as it stresses on individual consideration (van Engen et al., 2001). This assumption is further confirmed by the meta-analysis confirmed by Eagly et al. (2003). From their study, they conclude that women make more use of transformational leadership style than men, and make more use of contingent rewords (which is part of the transformational leadership style). According to them, men on the other hand make more use of active and passive management by exception.

Buchanan \& Huczynski (2004), further state that in leadership roles men and women use different conversational styles which can lead to misunderstandings; women tend to listen and reflect more while men tend to talk more and give information. According to Landy \& Conte (2004), it is clear that in the recent years the workplace is being transformed from one characterized by single contributors to one dominated by teams and interacting work groups. This in turn according to them suggests that people skills (e.g., communication, negotiation, conflict resolution) will become increasingly important and this would seem to favor women more as leaders. In his readings, Spector, (2006) also states that women would be more concerned with the feelings and emotional well-being of subordinates (consideration leadership style) while men would be more concerned with getting the job done (initiating structure leadership style) (Spector, 2006 p.6). Farrel (2005) argues that females are better leaders than men and when they actually go for the top they succeed better because of their female traits.

\subsection{Social Identity Theory and Perception of Followers}

Ever since the early 1970s, research in the field of social psychology has made great advancement in the study of social cognition and intergroup relations. Social identity theory has become one of the most important research areas of this advancement. In 1972, Tajfel introduced the concept of social identity theory, to examine how people view themselves in intergroup concepts, how a system of social classifications creates and defines a person's own place in society. Tajfel (1972) defined social identity as "the individual's knowledge that he/she belongs to certain social groups together with some emotional and value significance to him/her of this group membership".

According to Tajfel (1972), social identity theory operates in two parts. Firstly, it defines and evaluates a person (for example, she is a female manager). These types of definitions and evaluations are made both by others and by the person themselves. Secondly, this theory prescribes appropriate behavior for them. They think and behave in 
characteristically "female manger" ways and this happens through social comparison (Buchanan \& Huczynski, 2004).

Furthermore, Tajfel (1972) states that in order to evaluate their own opinions and abilities, people not only compare themselves to others with whom they interact, but also compare their own group with similar, but distinct, out-groups. The elements used to make such comparisons are called social categorizations. Categorizations, according to Buchanan \& Huczynski (2004), lead to assumptions of similarity among those who are categorized together. It minimizes the superficial differences between members of the in-group and maximizes the differences between the in-group and out-groups (in terms of us and them). According to Tajfel and Turner (1986), the out-groups will tend to be stereotyped. Once this happens, those who are part of the in-group will have assumed social identity, and from this standpoint, they will view others.

Continuing, in 2001, Hogg examined the social identity theory in relation to leadership. He describes leadership as "... how some individuals or cliques have disproportionate power and influence to set agenda, defines identity, and mobilizes people to achieve collective goals. The differential ability of some people to stamp their mark on attitudes, practices, decisions, and actions is endemic to all social groups-for example, nations, communities, organizations, committees, cliques, and families. Leaders are people who have disproportionate influence, through possession of consensual prestige or the exercise of power, or both, over the attitudes, behaviors, and destiny of group members. "(Hogg, 2001, 187)

Furthermore, Hogg (2001) proposed that three core processes exist which operate in combination to increase the influence of social identity in leadership processes. These three core processes are prototypicality, social attraction, and attribution and information processing. Attribution is specifically important and can be seen though perception of followers/employees/subordinates. Until now, most of the research on the topic has been performed on working businesspeople. In addition to this, the objective of this research is to study junior level employees and to test what their perceptions as well as the preferences are regarding this glass ceiling. Their results would be extremely valuable as they will be the future leaders of top companies, who could possibly reduce, if not totally eliminate, the gender inequality and the predominant gender stereotyping.

$\boldsymbol{H}_{1}$ : Compared to men, women are more favorably evaluated and more likely to be preferred for leadership positions in times of crisis as perceived by junior level employees.

$\boldsymbol{H}_{2}$ : Compared to women, men are more favorably evaluated and more likely to be preferred for leadership positions in times of no crisis as perceived by junior level employees.

\section{Methodology}

In order to investigate the hypotheses of the current study, a quantitative research is carried out. A method to explore the research question and hypotheses would be to conduct an online questionnaire to test the independent variable junior level employees' perceived suitability of male or female manager as a manager/leader and the independent variable company performance (declining: crisis situation or improving: no crisis situation) on the dependent variables. The dependent variables are the respondents' evaluation of the managers in the dimensions of (a) the managers' leadership ability and (b) the managers' suitability for the position according to the junior level employees' perception.

\subsection{Sample}

One-to-one questionnaire distribution and interviews were conducted based on convenience sampling over a period of 2 years with a total of 7 companies. After 20 sessions, at the end in total, 141 people have voluntarily participated in this experiment. All the respondents were junior employees who have less than 3 years of experience. Of the respondents $77(55 \%)$ were female and $64(45 \%)$ were male. The average age of the respondents was between the age group of 23 to 27 (52\%).

\subsection{Procedure, Measures and Data Analysis}

The questionnaire, which has been created for the current study, is based on Ryan \& Haslam's (2005a) measure of the class cliff phenomenon. However, instead of a laboratory experiment (which they have used) an online experiment by means of a questionnaire is created, where respondents answered to one of the four versions of the seven pages questionnaire. The first page consisted of a job advertisement for a desirable senior management position, a financial director for a large, international firm. 
Second pages differed for inclining group (improving performance scenario with company's stock values in growth trend graphs) and for declining (declining performance scenario with company's stock values in recession trend graphs)

Thereafter, participants were presented with a description and photograph of two managers for the advertised position. Both these managers were highly experienced, currently holding Financial Director positions and both having earned MBAs from prestigious business schools. The photographs were chosen after pilot testing so that Managers 1 and 2 were as similar as possible on all dimensions other than gender: they were both white and of equivalent age and attractiveness. The statements are designed to measure perceptions for: (a) the managers' leadership ability ('The manager would be a good leader', 'The manager has the skills and experience to lead other people', 'The manager has clear leadership credentials') and (b) the managers' suitability for the position ('The manager's past experience is relevant to the position', 'The manager will bring the required skills to the job', 'The manager is suitable for this position').

Participants were then asked to evaluate each of the managers by indicating their level of agreement with six statements (from 1, do not agree at all, to 7, agree completely). The statements were designed to measure perceptions of (a) the managers' leadership ability ('The manager would be a good leader', 'The manager has the skills and experience to lead other people', 'The manager has clear leadership credentials') and (b) the managers' suitability for the position ('The manager's past experience is relevant to the position', 'The manager will bring the required skills to the job', 'The manager is suitable for this position'). (Ryan \& Haslam, 2008, p 530)

\subsection{Results}

The data gathered in the experimental questionnaire is analyzed with the statistical program SPSS 21.0 for Windows. For testing each dependent variable separately a ANOVA was run, then the interaction of the independent variables and the covariates were checked against the six dependent, to see whether it provided any significant results. If indeed the relationship of the interactions was significant, a further analysis was conducted to measure the degree of the interaction by using a LSD post-hoc test.

The results of ANOVA test were not significant for variables "the manager would be a good leader" (p-value = 0.751), "The candidate has the skills and experience to lead other people" ( $\mathrm{p}$-value $=0.471)$,"The candidate has clear leadership credentials" ( $\mathrm{p}$-value $=0.303)$ and "The candidates past experience is relevant to the position" ( $\mathrm{p}$-value = 0.159). However 2 variables were found significant in ANOVA as:

The candidate will bring the required skills to the job $(p$-value $=0.087)$ with a post hoc test as shown in Table 1.

Table 1. LSD Post-Hoc Test for bring the required skills to the job

\begin{tabular}{|c|c|c|c|c|c|c|}
\hline \multicolumn{7}{|c|}{ Multiple Comparisons } \\
\hline \multicolumn{7}{|c|}{ bring the required skills to the job LSD } \\
\hline \multirow[t]{2}{*}{ (I) merge of } & \multirow[t]{2}{*}{ (J) merge of } & \multirow{2}{*}{$\begin{array}{c}\text { Mean } \\
\text { Difference } \\
(\mathrm{I}-\mathbf{J})\end{array}$} & \multirow[t]{2}{*}{$\begin{array}{l}\text { Std. } \\
\text { Error }\end{array}$} & \multirow[t]{2}{*}{ Sig. } & \multicolumn{2}{|c|}{$\begin{array}{l}\text { 95\% Confidence } \\
\text { Interval }\end{array}$} \\
\hline & & & & & $\begin{array}{l}\text { Lower } \\
\text { Bound }\end{array}$ & $\begin{array}{l}\text { Upper } \\
\text { Bound }\end{array}$ \\
\hline \multirow{3}{*}{$\begin{array}{r}\text { female } \\
\text { and crisis }\end{array}$} & male and crisis & .19 & .183 & .309 & -.17 & .55 \\
\hline & female and no crisis & .08 & .176 & .641 & -.27 & .43 \\
\hline & male and no crisis & -.18 & .187 & .334 & -.55 & .19 \\
\hline \multirow{3}{*}{$\begin{array}{l}\text { male and } \\
\text { crisis }\end{array}$} & female and crisis & -.19 & .183 & .309 & -.55 & .17 \\
\hline & female and no crisis & -.10 & .177 & .556 & -.45 & .25 \\
\hline & male and no crisis & -.37 & .188 & .053 & -.74 & .00 \\
\hline \multirow{3}{*}{$\begin{array}{c}\text { female } \\
\text { and no crisis }\end{array}$} & female and crisis & -.08 & .176 & .641 & -.43 & .27 \\
\hline & male and crisis & .10 & .177 & .556 & -.25 & .45 \\
\hline & male and no crisis & -.26 & .182 & .149 & -.62 & .10 \\
\hline \multirow{3}{*}{$\begin{array}{l}\text { male and } \\
\text { no crisis }\end{array}$} & female and crisis & .18 & .187 & .334 & -.19 & .55 \\
\hline & male and crisis & .37 & .188 & .053 & .00 & .74 \\
\hline & female and no crisis & .26 & .182 & .149 & -.10 & .62 \\
\hline
\end{tabular}


The results of Table 1 shows that the mean of the male candidate and crisis situation (mean $=2.47$ ) is significantly different $(\mathrm{p}$-value $=0.053)$ from the mean of male and no crisis $($ mean $=2.81)$.

These results indicate that when respondents are evaluating if the candidate (male or female) will bring the required skills to the job, the presence of a crisis has an effect only on the male candidate. Furthermore, these results also show that in a crisis situation male candidate's means are ranked lower than the overall mean by respondents when evaluating if the candidate will bring the required skills to the job. These findings suggest that male candidates are more likely to bring the required skills to the job when the company is not in a crisis situation, whereas they are less likely to bring the required skills to the job when the company is in a crisis situation.

The candidate is suitable for this position $(\mathrm{p}$-value $=0.077)$ with a post hoc test as shown in Table 2 .

Table 2. LSD Post-Hoc Test for "Suitable for this position"

\begin{tabular}{|c|c|c|c|c|c|c|}
\hline \multicolumn{7}{|c|}{ suitable for this position LSD } \\
\hline \multirow[t]{2}{*}{ (I) merge of } & \multirow[t]{2}{*}{ (J) merge of } & \multirow{2}{*}{$\begin{array}{l}\text { Mean Difference } \\
(\mathrm{I}-\mathrm{J})\end{array}$} & \multirow{2}{*}{$\begin{array}{l}\text { Std. } \\
\text { Error }\end{array}$} & \multirow[t]{2}{*}{ Sig. } & \multicolumn{2}{|c|}{ 95\% Confidence Interval } \\
\hline & & & & & $\begin{array}{l}\text { Lower } \\
\text { Bound }\end{array}$ & $\begin{array}{l}\text { Upper } \\
\text { Bound }\end{array}$ \\
\hline \multirow{3}{*}{$\begin{array}{l}\text { female and } \\
\text { crisis }\end{array}$} & male and crisis & .10 & .167 & .545 & -.23 & .43 \\
\hline & $\begin{array}{l}\text { female and no } \\
\text { crisis }\end{array}$ & .02 & .161 & .912 & -.30 & .34 \\
\hline & $\begin{array}{l}\text { male and no } \\
\text { crisis }\end{array}$ & $-.36^{*}$ & .171 & .037 & -.70 & -.02 \\
\hline \multirow[t]{3}{*}{ male and crisis } & $\begin{array}{l}\text { female and } \\
\text { crisis }\end{array}$ & -.10 & .167 & .545 & -.43 & .23 \\
\hline & $\begin{array}{l}\text { female and no } \\
\text { crisis }\end{array}$ & -.08 & .162 & .606 & -.40 & .24 \\
\hline & $\begin{array}{l}\text { male and no } \\
\text { crisis }\end{array}$ & $-.46^{*}$ & .173 & .008 & -.80 & -.12 \\
\hline \multirow[t]{3}{*}{$\begin{array}{l}\text { female and no } \\
\text { crisis }\end{array}$} & $\begin{array}{l}\text { female and } \\
\text { crisis }\end{array}$ & -.02 & .161 & .912 & -.34 & .30 \\
\hline & male and crisis & .08 & .162 & .606 & -.24 & .40 \\
\hline & $\begin{array}{l}\text { male and no } \\
\text { crisis }\end{array}$ & $-.38^{*}$ & .166 & .025 & -.71 & -.05 \\
\hline \multirow[t]{3}{*}{$\begin{array}{l}\text { male and no } \\
\text { crisis }\end{array}$} & $\begin{array}{l}\text { female and } \\
\text { crisis }\end{array}$ & $.36^{*}$ & .171 & .037 & .02 & .70 \\
\hline & male and crisis & $.46^{*}$ & .173 & .008 & .12 & .80 \\
\hline & $\begin{array}{l}\text { female and no } \\
\text { crisis }\end{array}$ & $.38^{*}$ & .166 & .025 & .05 & .71 \\
\hline \multicolumn{7}{|c|}{ Based on observed means. } \\
\hline
\end{tabular}

The results of Table 3 shows that the mean of the male candidate and no crisis situation $($ mean $=2.87)$ is significantly different from the mean of male and crisis (mean $=2.44, \mathrm{p}$-value $=0.008)$, the mean of female candidate and crisis $($ mean $=2.54, \mathrm{p}$-value $=0.037)$ and the mean of female candidate and no crisis $($ mean $=2.52$, $\mathrm{p}$-value $=0.025$ ). These results indicate that when respondents are evaluating if the candidate (male or female) is suitable for this position, the male candidate under a no crisis situation is evaluated as significantly higher than all the other means. The female candidate is rated indifferent for company performance in both crisis and no crisis 
situation (this is especially visible from figure 3 , which shows an almost horizontal line when evaluating the female candidate). These finding suggest that male candidates are more likely to be suitable for this job position when the company is not in a crisis situation, whereas they are less likely to be suitable for this job position when the company is in a crisis.

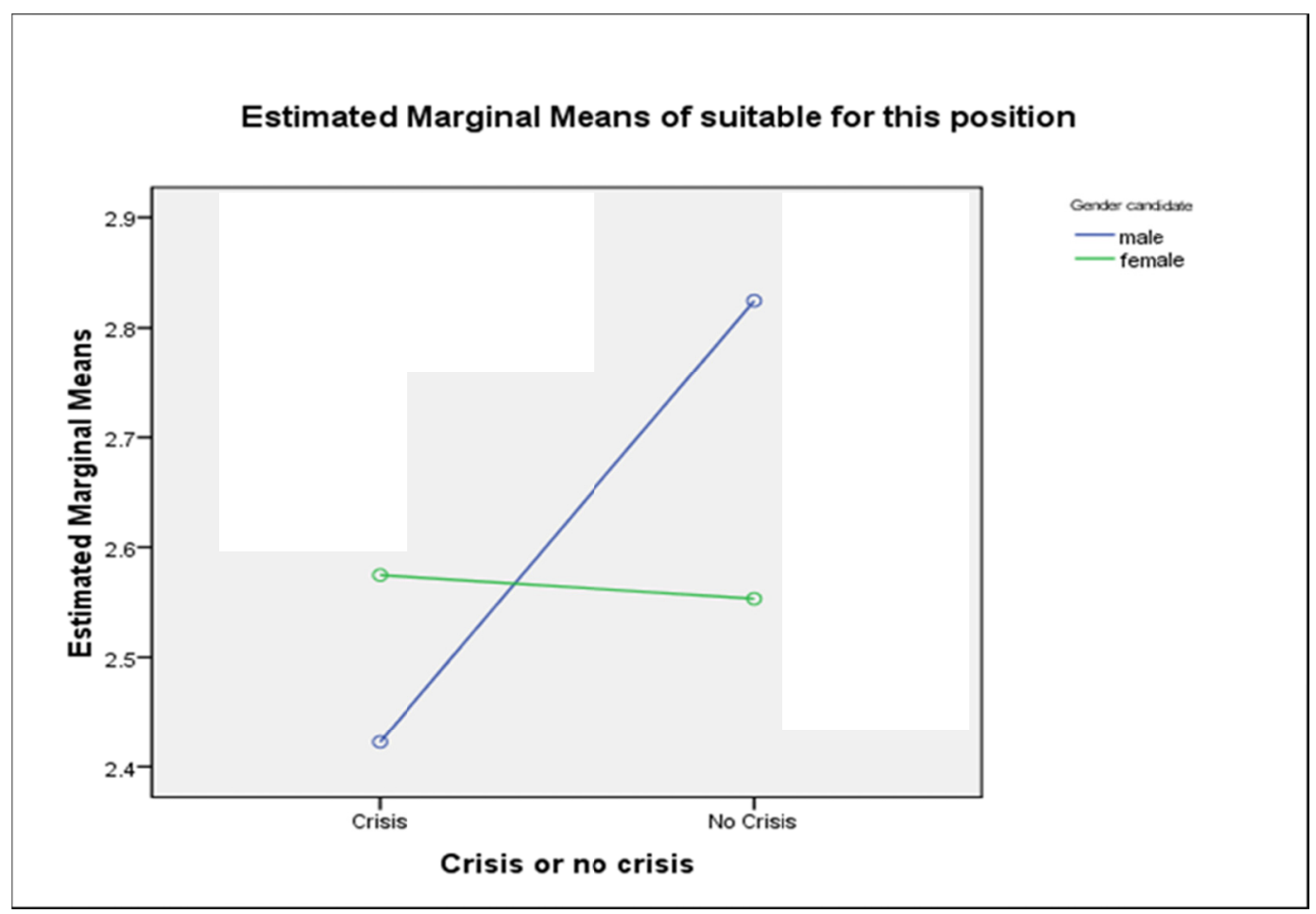

Figure 3. The candidate is suitable for this position

Furthermore, since the conceptual model of the current study, based on the research conducted by Ryan \& Haslam (2005a), suggested two factors: (1) the potential candidates' leadership ability and (2) the potential candidates' suitability for the position., The Bartlett's test of Sphericity $(\mathrm{p}<.000)$ and KMO test $(\mathrm{KMO}=.817)$ were used and verified that the factor analysis is feasible to be tested and in order to rotate the solution indicated that of the six variables, the first three variables correlated with each other and the last three variables correlated with each other, as a result forming two factors (this is also in accordance with the theory of Ryan \& Haslam, 2005a).

Factor 1 was named as Leadership Ability, (which measured the total values of the first three variables and that divided by three) belonging to the candidates' leadership ability and factor 2 was named as Suitability, (which measured the total values of the last three variables and that divided by three) belonging to the candidates' suitability for the position.

The sufficiently high values of Cronbach $\alpha$ in each factor indicate a high reliability of the two examined factors. The total variance explained by the two factors $(68.996 \%)$ is adequately satisfying.

The results of the ANOVA indicate that the interaction of company performance and the gender of the candidate on the dependent variable 'the leadership ability of the candidate' were insignificant ( $p$-value $=0.632$ ).

However, results of the ANOVA indicate that the interaction of company performance and the gender of the candidate on factor "suitability" is significant ( $\mathrm{p}$-value $=0.050$ ) 
Table 3. LSD Post-Hoc Test for "Suitability"

\begin{tabular}{|c|c|c|c|c|c|c|}
\hline $\begin{array}{l}\text { Suitability } \\
\text { LSD }\end{array}$ & & & & & & \\
\hline \multirow[t]{2}{*}{ (I) merge of } & \multirow[t]{2}{*}{ (J) merge of } & \multirow[t]{2}{*}{$\begin{array}{c}\text { Mean } \\
\text { Difference (I-J) }\end{array}$} & \multirow[t]{2}{*}{$\begin{array}{l}\text { Std. } \\
\text { Error }\end{array}$} & \multirow[t]{2}{*}{ Sig. } & \multicolumn{2}{|c|}{$\begin{array}{l}95 \% \text { Confidence } \\
\text { Interval }\end{array}$} \\
\hline & & & & & $\begin{array}{l}\text { Lower } \\
\text { Bound }\end{array}$ & $\begin{array}{l}\text { Upper } \\
\text { Bound }\end{array}$ \\
\hline \multirow{3}{*}{$\begin{array}{l}\text { female and } \\
\text { crisis }\end{array}$} & male and crisis & .1277 & .15376 & .408 & -.1763 & .4318 \\
\hline & $\begin{array}{l}\text { female and no } \\
\text { crisis }\end{array}$ & .0405 & .14780 & .785 & -.2518 & .3327 \\
\hline & $\begin{array}{l}\text { male and no } \\
\text { crisis }\end{array}$ & -.2491 & .15618 & .113 & -.5579 & .0597 \\
\hline \multirow[t]{3}{*}{ male and crisis } & $\begin{array}{l}\text { female and } \\
\text { crisis }\end{array}$ & -.1277 & .15376 & .408 & -.4318 & .1763 \\
\hline & $\begin{array}{l}\text { female and no } \\
\text { crisis }\end{array}$ & -.0873 & .14895 & .559 & -.3818 & .2073 \\
\hline & $\begin{array}{l}\text { male and no } \\
\text { crisis }\end{array}$ & $-.3768^{*}$ & .15728 & .018 & -.6878 & -.0658 \\
\hline \multirow[t]{3}{*}{$\begin{array}{l}\text { female and no } \\
\text { crisis }\end{array}$} & $\begin{array}{l}\text { female and } \\
\text { crisis }\end{array}$ & -.0405 & .14780 & .785 & -.3327 & .2518 \\
\hline & male and crisis & .0873 & .14895 & .559 & -.2073 & .3818 \\
\hline & $\begin{array}{l}\text { male and no } \\
\text { crisis }\end{array}$ & -.2896 & .15145 & .058 & -.5891 & .0099 \\
\hline \multirow[t]{3}{*}{$\begin{array}{l}\text { male and no } \\
\text { crisis }\end{array}$} & $\begin{array}{l}\text { female and } \\
\text { crisis }\end{array}$ & .2491 & .15618 & .113 & -.0597 & .5579 \\
\hline & male and crisis & $.3768^{*}$ & .15728 & .018 & .0658 & .6878 \\
\hline & $\begin{array}{l}\text { female and no } \\
\text { crisis }\end{array}$ & .2896 & .15145 & .058 & -.0099 & .5891 \\
\hline \multicolumn{7}{|c|}{$\begin{array}{l}\text { Based on observed means. } \\
\text { The error term is Mean Square (Error) }=.408 \text {. }\end{array}$} \\
\hline $\begin{array}{l}\text { *. The mean } \\
\text { level. }\end{array}$ & ference is signifi & th at the 0.05 & & & & \\
\hline
\end{tabular}

The results of Table 3 shows that the mean of the male candidate and no crisis situation $($ mean $=2.9063)$ is significantly different $(\mathrm{p}$-value $=0.018)$ from the mean of male candidate and crisis $($ mean $=2.5294)$ and the mean of female candidate and no crisis $($ mean $=2.6167, \mathrm{p}$-value $=0.058)$. These results indicate that when respondents are evaluating if the candidate (male or female) is suitable for this position, the male candidate under a no crisis situation is evaluated (1) higher than a male candidate under crisis situation and (2) higher than a female under no crisis situation. The female candidate is not affected by the presence of a crisis (this is especially visible from Figure 4). Finally, there are gender effects in a crisis situation. However, in a non crisis situation, there are indeed significant differences between a male and female candidate. Overall, male candidates are significantly rated higher than female candidates. 


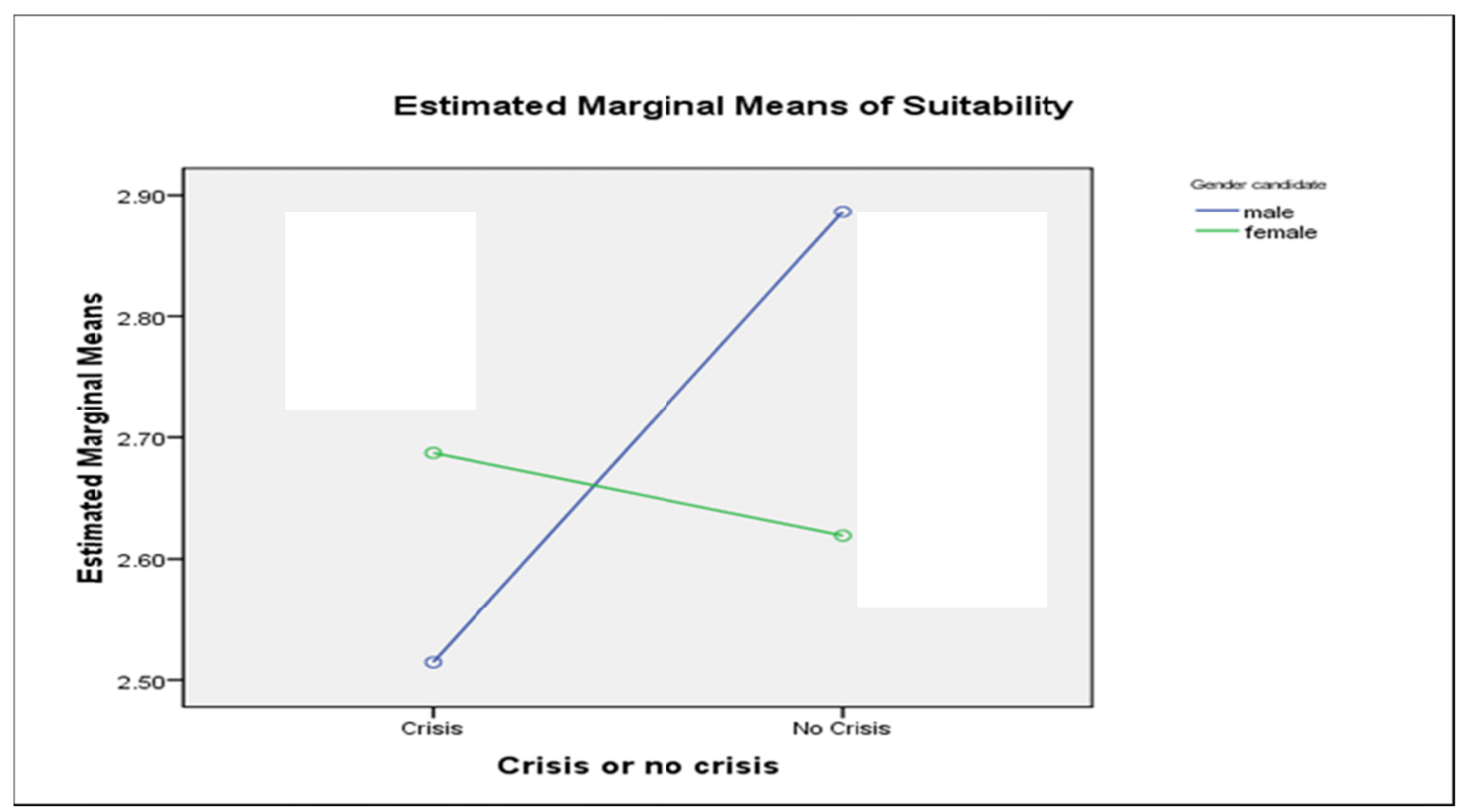

Figure 4. Suitability of candidate to the position

These finding suggest that male candidates are more likely to be suitable for this job position when the company is not in a crisis situation, whereas they are less likely to be suitable for this job position when the company is in a crisis situation.

\section{Discussions and Conclusions}

According to the results mentioned above, when examining the results of the dependent variable "the suitability of the candidate' in greater detail, the following can be concluded regarding the hypotheses testing. The results for the dependent variable (factor 2), on the basis of ANOVA and LSD post-hoc testing shows that when respondents are evaluating if the candidate (male or female) will 'will be suitable for this position', only the male candidate is evaluated with significant results. The female candidate is rated indifferent for company performance in both crisis and no crisis situation.

These findings imply that male candidates are more likely to 'be suitable for the position' when the company is not in a crisis situation, whereas they are less likely to 'be suitable for the position' when the company is in a crisis situation. For the above mentioned reasons, there is evidence to support hypothesis two which states that compared to women, men will be more favorably evaluated and more likely to be recommended for leadership positions in a company when its performance is improving rather than declining. And as a result, reject hypothesis one.

Although the other dependent variable 'candidates leadership ability' showed no significant results, and by this neither hypothesis one or two could be supported, the dependent variable did show a pattern for the interaction between the company performance and the dependent variable which is somewhat in line with hypothesis two. This dependent variable showed that respondents were more inclined to rate a candidate (which is genderless as there was no significance for the gender of the candidate) higher when company performance was improving rather than declining. Although hypothesis two does take gender of the candidate into it, the remaining part of hypothesis two states that a candidate is more likely to be recommended when the performance of the company is improving rather than declining. Even though there is no support for hypothesis two as it does not take gender into account, it is important to note this pattern of the respondents who rate candidates higher in a no crisis situation and rate them lower in a crisis situation.

In line with hypothesis two, evaluations of the two candidates by respondents revealed that when company performance was not in a crisis, the male candidate was seen (a) as more suitable for the position and (b) as having more leadership ability, than an identically qualified female candidate. This finding also partially supports the glass cliff phenomenon, that being participants' ideal leader in a healthy company is associated with "think manager-think 
male" and that men have the luxury to not accept leadership positions which have a high risk of failure (in order not to lose face) and are therefore found in leadership positions in companies which are improving.

Furthermore, hypothesis two is further supported by theorists such as Loden (1985), who suggests that men have a more masculine leadership style, including traits like competitiveness, hierarchy, power and the ability of making decisions based on analytical thinking and Spector (2006), who suggests that men would be more concerned with getting the job done. These gender difference stereotyping suggest that male leaders seem to have better leadership ability and therefore seem to be more suitable for the position when compared to an identically qualified female candidate. The respondents of the current study may have been influenced by such stereotyping at one point and as a result evaluated the male candidate higher in times of no crisis.

Continuing, evaluations of the two candidates by respondents revealed that when company performance was in a crisis situation, the male and female candidates were seen as indifferent regarding (a) the suitability for the position and (b) as having more leadership ability and were hence not in line with hypothesis one and ultimately the research question of this current study.

According to the research of Ryan and Haslam (2005), which found clear evidence that women were preferentially selected for precarious leadership positions associated with organizations in crisis, this study provided no such evidence, as hypothesis one was never accepted. On the contrary, this research suggests that respondents are mainly indifferent about the gender of the leader when a company is in a crisis situation. The interactions between the gender of the candidate and the performance of the company indicated that both men and women were likely to be placed in (or be seen as suitable for) leadership positions that were in crisis and hence associated with an increased risk of failure.

Although the analysis of the current research is based on a limited number of participant and small sample presentation, the statistical results of this study are extremely interesting and can contribute to the research, as it has found evidence against the glass cliff phenomenon, such that both women and men are likely to be chosen to lead companies which are in crisis and risk the chance of failure. On the basis of these results the glass cliff phenomenon could possibly be seen as gender neutral. This would imply that both women and men could end up in precarious leadership positions in a company even though the glass cliff phenomenon states that precarious positions are offered only to women and minorities, as an opportunity to break through the glass ceiling (Frazier and Hunt, 1998).

Furthermore, the results of this study could also indicate that the glass cliff phenomenon does not have to be so negative, that like men, women could also decline leadership positions in companies who are in a crisis and have the luxury to wait for a better position to come along. In essence the glass cliff might be more like a glass road, and that women need to take this opportunity to use their female qualities as transformational leaders and show their value to the organization both in times of no crisis and crisis. This, in order to prove, that they are not expendable and that their transformational leadership abilities will help subordinates and ultimately the company to perform better.

Naturally, it is not correct to decline the findings of Ryan and Haslam (2004) of the glass cliff phenomenon because this study showed no evidence to support it. Next to their results, many theorists have also pointed to the barriers and challenges that women face when trying to break through the glass ceiling. As to date, no single indicator shows that the economic conditions of women in the world, as a whole, are at parity with the conditions of men (Calas and Smircich, 2006). However, this study shines some-what positive light on the theories of leadership style and gender differences, this being that discrimination and stereotypes are perhaps reducing in effect for the future leaders (the business students) and their perceptions regarding the differences in leadership abilities of men and women leaders in crisis situations. In addition to this, the transformational leadership style which is commonly associated with females and crisis situations, may possibly also need revision in order to bring the theory up to date, as the respondents of this current study do not associate females belonging to this leadership style and also do not perceive them to perform better than male leaders in times of crisis.

Furthermore, this positive light could both be supported and not supported by the social identity theory. As the results of this study indicated that there were no significant differences in the evaluations of male and female respondents in times of crisis. This means that in-group and out-group favoritism did not exist for both genders. Female respondents did not rank female candidates higher and male respondents did not rank male candidates higher with regards to their leadership abilities and suitability for the position. However, although no significant differences also existed in the evaluations of the male and female respondents in a no crisis situation, in-group favoritism did hold for the male student respondents, as they rated the male candidates higher, but no out-group favoritism existed for the female respondents. Meaning, female students also favored the male candidate to be a better leader in times of no crisis, like the male respondents did. 
This is a very intriguing finding and could suggest alternative interpretations to the social identity theory. It may well be that females do not have as strong identification with their social group as males, or that they are not as interested in convincing others (the out-group) that their in-group is more suitable (or just as capable) for a particular situation. Furthermore, perhaps the notion of female leaders as a social identity group still needs to develop. For example, men have been in top positions for years and their social identity has been communicated and accepted in all levels for many decades (e.g. old boys' network). However, such identifications and recognitions for females are only in existence for the past two to three decades and it has not yet found its solid ground in all parts of our society. As a result, this could explain why females also opted for the male candidate as suitable for the position in a no crisis situation, instead of favoring their in-group, that being the female leader.

Although the gender of the respondents was not found to play a role in determining if male or female candidates would be perceived to be the better leaders in a company crisis situation, further investigation into the gender of the respondent is needed. According to the social identity theory, the degree to which individuals will support particular explanations for group-based phenomenon is likely to be influenced by identity-based motivations. Men and women display very different patterns of theorizing about gender discrimination (e.g., Barreto \& Ellemers, 2005). This suggests that individuals' explanations for the existence of glass cliffs are likely to vary predictably as a function of the form and extent of their identification with their gender group and their perceptions of the status relations between men and women (Ryan et al., 2007). Continuing, future research could continue to examine the glass cliff phenomenon and the social identity theory for the discrimination of women and minorities after they have passed through the glass ceiling. Perhaps the identification of why men discriminate women and minorities for job positions on the basis of the social identity theory can explain why the glass cliff phenomenon has come to existence.

\section{References}

Arfken, D. E., Bellar, S. L., \& Helms, M. M. (2004). The ultimate glass ceiling revisited: The presence of women on $\begin{array}{lllll}\text { board } \text { rooms. Journal of Business } & \text { 177-186. }\end{array}$ http://dx.doi.org/10.1023/B:BUSI.0000022125.95758.98

Arvey, R. D. (1979). Unfair discrimination in the employment interview: Legal and psychological aspects. Psychological Bulletin, 86, 736-765. http://dx.doi.org/10.1037/0033-2909.86.4.736

Barreto, M., \& Ellemers, N. (2005). The perils of political correctness: responses of men and women to old-fashioned and modern sexism. Social Psychology Quarterly, 68(1), 75-88. http://dx.doi.org/10.1177/019027250506800106

Berson, Y., Shamir, B., Avolio, B. J., \& Popper, M. (2001). The relationship between vision strength, leadership style, and context. The Leadership Quarterly, 12(1), 53-73. http://dx.doi.org/10.1016/S1048- 9843(01)00064-9

Buchanan, D., \& Huczynski, A. (2004). Organizational Behaviour: An Introductory Text. New York: Prentice Hall.

Bureau of Labor Statistics. (2005). Current Population Survey. Retrieved from http://www.bls.gov/bls/databooknews2005.pdf

Burns, J. M. (1978). Leadership. New York: Harper\&Row.

Calas, M., \& Smircich, L. (2006). From the 'Women's Point of View' Ten Years Later: Towards a Feminist Organization Studies. In Clegg, S. T., Hardy, C. \& Nord, W. R. (Eds.), Handbook of Organization Studies (pp. 284-346). London: Sage.

Conger, J. A., \& Kanungo, R. N. (1987). Towards a behavioral theory of charismatic leadership in organizational settings. Academy of Management Review, 12, 637-647. http://dx.doi.org/10.5465/AMR.1987.4306715

Dreher, G. F. (2003). Breaking the glass ceiling: The effects of sex ratios and work-life programs on female leadership at the top. Human Relations, 56, 541-562 http://dx.doi.org/10.1177/0018726703056005002

Eagly, A. H. (1995). The science and politics of comparing men and women. American Psychologist, 50, 145-158. http://dx.doi.org/10.1037/0003-066X.50.3.145

Eagly, A. H., \& Johnson, B. T. (1990). Gender and leadership style: A meta-analysis. Psychological Bulletin, 108(2), 233-256. http://dx.doi.org/10.1037/0033-2909.129.4.569

Eagly, A. H., Johannesen-Schmidt, M. C., \& van Engen, M. L. (2003). Transformational, transactional, and laissez-faire leadership styles: A meta-analysis comparing women and men. Psychological Bulletin, 129(4), 569-591. http://dx.doi.org/10.1037/0033-2909.129.4.569

Farrel, W. (2005). Why men earn more. Amacon. New York. 
Fiedler, F. E. (1967). A theory of leadership effectiveness. New York: McGraw-Hill.

Frazier, P. A., \& Hunt, J. A. (1998) Research on gender and the law: Where are we going, where have we been? Law and Human Behavior, 22, 1-16. http://dx.doi.org/10.1023/A:1025774920650

Gilligan, C. (1977). In a different voice: Women's conception of self and of morality. Harvard Educational Review, $47,481-517$.

Goodman, J. S., Fields, D. L., \& Blum, T. C. (2003). Cracks in the glass ceiling: In what kinds of organizations do women make it to the top?. Group and Organization Management, 475-501. http://dx.doi.org/10.1177/1059601103251232

Hogg, M. A. (2001). A social identity theory of leadership. Personality and Social Psychology Review, 5(3), 184-200. http://dx.doi.org/10.1207/S15327957PSPR0503_1

Horner, M. (1972). Toward an understanding of achievement-related conflicts in women, Journal of Social Issues, 28, 157-174. http://dx.doi.org/10.1111/j.1540-4560.1972.tb00023.x

House, R. J., \& Baetz, M. L. (1979). Leadership, Some empirical generalizations and new research directions. In B. M. Staw (Ed.), Research in organizational behavior, (Vol. 1, pp. 399-401). http://dx.doi.org/10.5465/AMR.1987.4306715

Hyde, J. S., \& Plant, E. A. (1995). Magnitude of psychological gender differences: Another side to the story. American Psychologist, 50, 159-161. http://dx.doi.org/10.1037/0003-066X.50.3.159

International Labor Organization. (2004). Global Employment Trends for Women. Geneva: ILO.

Kelly, M., Davis, K. M., \& Gardner, W. L. (2012). Charisma under crisis revisited: Presidential leadership, perceived leader effectiveness, and contextual influences. The Leadership Quarterly (23), 918-933 http://dx.doi.org/10.1016/j.leaqua.2012.06.001

Kirkpatrick, S. A., \& Locke, E. A. (1991). Leadership: do traits matter? Academy of Management Executive, 5(2), 48-60. http://dx.doi.org/10.5465/AME.1991.4274679

Landy, F. J., \& Conte, J. M. (2004). Work in the 21st Century. An introduction to industrial and organizational psychology. New York: McGraw-Hill, Inc.

Lefkoitz, J. (1994). Sex-related differences in job attitudes and dispositional variables: Now you see them... Academy of Management Journal, 37, 323-349. http://dx.doi.org/10.2307/256832

Lerbinger O. (2012). Facing Disasters, Conflicts, and Failures. Taylor \& Francis 711 Third Avenue, New York, NY 10017

Loden, M. (1985). Feminine leadership of how to succeed in business without being one of the boys. New York: Times Books.

Mann, S. (1995). Politics and power in organizations: why women lose out. Leadership and Organization Development Journal, 16(2), 9-15. http://dx.doi.org/10.1108/01437739510082271

Maume, D. J. (2004). Is the glass ceiling a unique form of inequality? Work and Occupations, 31(2), 250-274. http://dx.doi.org/10.1177/0730888404263908

Michelle K., Haslam S. A., \& Hersby M. D. (2010). Think Crisis-Think Female: The Glass Cliff and Contextual Variation in the Think Manager-Think Male Stereotype. Journal of Applied Psychology, 96(3), 470-489 http://dx.doi.org/10.1037/a0022133

Moran, R. T., Remington, N. A., \& Moran, S. V. (2011). Managing Cultural Differences Butterworth-Heinemann Routledge 2 Park Square, Milton Park, Abingdon, Oxon OX14 4RN.

Ridgeway, C. L. (2001). Gender, status, and leadership. Journal of Social Issues, 57(4), 637-655. http://dx.doi.org/10.1111/0022-4537.00233

Ruble, T. L. (1983). Sex stereotypes: Issues of change in the 1970s. Sex Roles, 9(3), 397-402. http://dx.doi.org/10.1007/s11199-010-9902-3

Ryan, M. K., \& Haslam, S. A. (2004). Introducing the glass cliff, online BBC article. Retrieved from http://news.bbc.co.uk/1/hi/magazine/3755031.stm 
Ryan, M. K., \& Haslam, S. A. (2005a). The glass cliff: Evidence that women are over-represented in precarious leadership positions. British Journal of Management, 16, 81-90. http://dx.doi.org/10.1111/j.1467-8551.2005.00433.x

Ryan, M. K., \& Haslam, S. A. (2007). The glass cliff: Exploring the dynamics surrounding the appointment of women to precarious leadership positions. Academy of Management Review, 32(2), 549-572. http://dx.doi.org/10.5465/AMR.2007.24351856

Ryan, M. K., \& Haslam, S. A. (2008). The road to the glass cliff: Differences in the perceived suitability of men and women for leadership positions in succeeding and failing organizations. The Leadership Quarterly, 19(2008), 530-546. http://dx.doi.org/10.1016/j.leaqua.2008.07.011

Ryan, M. K., Haslam, S. A., \& Postmes, T. (2007). Reactions to the glass cliff. Gender differences in the explanations for the precariousness of women's leadership positions. Journal of Organizational Change Management, 20(2), 182-197. http://dx.doi.org/10.1108/09534810710724748

Schein, V. E. (1973). The Relationship between Sex-role Stereotypes and Requisite Management Characteristics. Journal of Applied Psychology, 57(2), 95-100. http://dx.doi.org/10.1037/h0037128

Schwartz, F. N. (1994). Management women and the new facts of life. In N.A. Nichols (Ed.), Reach for the top: Women and the changing facts of work life. Harvard Business School Publishing, Boston, MA.

Spector, P. E. (2006). Industrial and organizational psychology. Research and practice. Hoboken, John Wiley \& Sons, Inc.

Strange, J. M., \& Mumford, M. D. (2002). The origins of vision: Charismatic versus ideological leadership. The Leadership Quarterly, 13(4), 239-270. http://dx.doi.org/10.1016/j.leaqua.2004.07.006

Tajfel, H. (1972). Social categorization. (English translation of "La cat6gorisation sociale"). In S. Moscovici (Ed.), Introduction a la psychologie sociale (vol. 1, pp. 272-302).

Tajfel, H., \& Turner, J. C. (1986). The social identity theory of intergroup behavior. In S. Worchel \& W. G. Austin (Eds.), The psychology of intergroup relations (pp. 7-24). Chicago: Nelson-Hall.

Van Engen, M. L., van der Leeden, R., \& Willemsen, T. M. (2001). Gender, context and leadership syles: a field study. Journal of Occupational and Organizational Psychology, 74(5), 581-598. http://dx.doi.org/10.1348/096317901167532

Willner, A. R. (1984). The spellbinders: charismatic political leadership. In G. Yukl, Leadership in organizations. New Jersey: Prentice-Hall, Inc.

Yukl, G. (1998). Leadership in organizations ( $4^{\text {th }}$ ed.). Upper Saddle River, NJ: Prentice Hall. 